\title{
Control of infection in general practice: a survey and recommendations
}

\author{
P N Hoffman, E M Cooke, D P Larkin, L J Southgate, R T Mayon-White, J V S Pether, A E Wright, \\ D Keenlyside
}

\begin{abstract}
Twenty general practices in four areas in Britain were surveyed to establish their needs for and practices of sterilising and disinfecting equipment. Of the 327 items of equipment and instruments examined in the survey, 190 were satisfactorily decontaminated, 100 were treated in a way judged to result in doubtful decontamination, and in $\mathbf{3 7}$ cases treatment was considered unsatisfactory. Decontamination apparatuses (autoclaves, hot air ovens, and hot water disinfectors) were generally in good working order, but the use of chemical disinfectants was often inappropriate. Recommendations were made on appropriate methods of decontamination for various items in common use in general practice.

By virtue of the large numbers of patients treated by general practitioners there is a substantial possibility of transmitting infection; having appropriate methods for decontaminating instruments and equipment is therefore imperative.
\end{abstract}

Division of Hospital

Infection, Central Public

Health Laboratory,

London

NW95HT

P N Hoffman, BSC, senior

microbiologist

E M Cooke, FRCPATH,

director

D P Larkin, BSC,

microbiologist

Department of General

Practice, St Bartholomew's

Hospital Medical College,

New Science Block,

London EC1

L J Southgate, FRCGP, senior lecturer

Department of Community Medicine, Manor House, Oxford OX3 9DZ

R T Mayon-White, FFCM, community physician

Public Health Laboratory, Taunton and Somerset Hospital, Musgrove Park Branch, Taunton TA1 5DB J V S Pether, FRCPATH, consultant microbiologist

General Hospital,

Newcastle upon Tyne NE4 6BE

A E Wright, FRCPATH, director, public health laboratory

D Keenlyside, RGN, infection control nursing officer

Correspondence to: $\mathrm{Mr}$ Hoffman.

\section{Introduction}

Infection control in domiciliary practice has attracted less attention than it has in hospitals, though the large number of patients treated gives substantial opportunity for transmission of infection. The emergence of human immunodeficiency virus and human papillomavirus and a greater awareness of hepatitis B have initiated reappraisal of decontamination facilities available to and needed in general practice. This survey was used to ascertain the scope of the problem and to serve as a basis for recommendations about infection control. In it we examined the use of instruments and equipment that may be capable of transferring microbial contamination to patients, either from other patients (the most probable source of hazard) or from the environment. We also assessed the availability and efficacy of decontamination by various means. These included sterilisation, either by using steam under pressure in an autoclave or by using dry heat in a hot air oven, and disinfection (the reduction but not necessarily total elimination of infectious agents), either by hot water disinfectors or with chemical disinfectants.

\section{Method}

The survey was split among four areas in the United Kingdom (the north east, the midlands, the south west, and inner London). These provided a cross section of geographical locations and area-that is, inner and outer urban and rural. Five practices in each area were recruited into the survey by people with established links with local general practitioners. Each practice was visited by a member of the survey team and a questionnaire completed in consultation with either the principals, the practice nurse, or both. One team member (PNH) either was present at each visit or made the first two visits with the local team in each area to standardise survey methods.

The questionnaire asked for details about the location of the practice, the number of partners and the list size, whether there was a practice nurse, what decontamination facilities were available and how technically efficient and well maintained they were, what instruments and equipment were used, and how they were decontaminated. The efficacy of decontamination was judged in the context of the risks that the instruments posed to patients, ${ }^{1}$ classified as high (instruments introduced into any sterile body area or in close contact with a break in either skin or mucous membrane), medium, (those in close contact with intact mucous membrane or which may accidentally or occasionally come into contact with breaks in the skin), and low (instruments that come into contact with intact skin). Table I lists the instruments and equipment examined in the survey and the infection control methods that we set as standards. The most efficient method of decontamination is sterilisation in either an autoclave or a hot air oven, which should be used for high risk items. An equivalent is to use presterile single use items. This is followed by high level disinfection by heat, usually boiling water, which is appropriate to the

TABLE I-Recommended methods for instrument decontamination and usage in general practice

\begin{tabular}{|c|c|c|}
\hline & $\begin{array}{l}\text { Recommended } \\
\text { methods }\end{array}$ & $\begin{array}{l}\text { Acceptable } \\
\text { alternatives }\end{array}$ \\
\hline \multicolumn{3}{|l|}{$\begin{array}{l}\text { High risk items: } \\
\text { Surgical scissors and forceps } \\
\text { Stitch cutters }\end{array}$} \\
\hline $\begin{array}{l}\text { Intrauterine device sets } \\
\text { Uterine sounds } \\
\text { Tenaculums }\end{array}$ & \multirow[t]{2}{*}{$\begin{array}{r}\text { Sterilise or single } \\
\text { use (presterile) }\end{array}$} & \multirow[t]{2}{*}{ None } \\
\hline $\begin{array}{l}\text { Neurological examination } \\
\text { pins }\end{array}$ & & \\
\hline \multicolumn{3}{|l|}{$\begin{array}{l}\text { Medium risk items: } \\
\text { Vaginal speculums } \\
\text { Fitting rings/diaphragms } \\
\text { Ring pessaries } \\
\text { Proctoscopes/ } \\
\text { sigmoidoscopes }\end{array}$} \\
\hline $\begin{array}{l}\text { Auriscope "nozzles" } \\
\text { Laryngeal mirrors } \\
\text { Nasal speculums } \\
\text { Tongue depressors } \\
\text { Peak flow meter } \\
\text { mouthpieces }\end{array}$ & $\begin{array}{l}\text { Sterilise or single } \\
\text { use }\end{array}$ & $\begin{array}{l}\text { Boil if suitable } \\
\text { or none }\end{array}$ \\
\hline Thermometers-oral/rectal & $\begin{array}{l}70 \% \text { Alcohol for } 10 \\
\text { minutes or single } \\
\text { use }\end{array}$ & None \\
\hline \multicolumn{3}{|l|}{ Low risk items: } \\
\hline Ear syringe nozzles & Sterilise or boil & $\begin{array}{l}\text { Chemical } \\
\text { disinfection } \\
\text { or wash }\end{array}$ \\
\hline Skin thermometers & $\begin{array}{l}70 \% \text { Alcohol for } 10 \\
\text { minutes or single } \\
\text { use }\end{array}$ & Wash \\
\hline
\end{tabular}


decontamination of items in the medium risk group. Single use items may also be used in this category but there is no requirement for them to be presterilised. Chemical disinfectants may be used with care for thermolabile medium risk items and for all low risk items.

The decontamination practices found were deemed to be satisfactory if they matched either the preferred method or an acceptable alternative, doubtful if they were appropriate for the next lower risk category-for example, heat disinfection for an instrument which should have been sterilised-or unsatisfactory if the treatment fell substantially short of a satisfactory decontamination method-for example, chemical disinfection in place of sterilisation, or washing in place of heat disinfection.

Thermometric tests were made on autoclaves, hot air ovens, and hot water disinfectors that used temperatures lower than boiling. Parameters of sterilisation cycles were assessed for efficacy and inquiries made into service contracts and service intervals for autoclaves and hot water disinfectors. A general appraisal of disinfectant use was made and disinfectants in use sampled to detect bacterial contamination.

\section{Results}

The 20 practices in the survey had a mean of four partners (range one to eight) and a mean of 2200 patients per partner. Ten practices were located in inner cities, four in outer urban areas, and six were rural. Thirteen employed practice nurses. Five practices had autoclaves, one had a hot air oven, 13 had hot water disinfectors (one used both an autoclave and a hot water disinfector), and two had no means of heat decontamination; one of these practices, however, could have instruments sterilised in a local hospital's central sterile supply deparment. Practices having some means of sterilisation (either an autoclave or hot air oven) tended to be the larger ones, with an average of around six partners (range three to eight), compared with those which had no sterilisation apparatus
TABLE II-Survey results classified by instrument risk group

\begin{tabular}{lllc}
\hline & \multicolumn{3}{c}{$\begin{array}{c}\text { Overall decontamination assessment }(\%) \\
\text { (actual numbers in parentheses) }\end{array}$} \\
\cline { 2 - 4 } $\begin{array}{l}\text { Risk } \\
\text { category }\end{array}$ & \multicolumn{1}{c}{ Satisfactory } & \multicolumn{1}{c}{ Doubtful } & Unsatisfactory \\
\hline High & $56(60 / 108)$ & $31(34 / 108)$ & $13(14 / 108)$ \\
Medium & $56(106 / 190)$ & $32(61 / 190)$ & $12(23 / 190)$ \\
Low & $83(24 / 29)$ & $17(5 / 29)$ & - \\
\hline
\end{tabular}

(average around three partners; range one to seven).

Table II shows the decontamination practices for the instruments and equipment. The commonest cause of doubtful decontamination among high risk instruments resulted from hot water disinfection (usually boiling) being used instead of sterilisation, and most unsatisfactory decontamination in this category was the result of chemical disinfection; an exception was for neurological examination pins, five users reusing them without decontamination. The nine remaining unsatisfactory treatments recorded for high risk items included those for scissors used surgically in three practices, metal forceps used surgically in four, and the uterine sounds and tenaculums used in one practice, all of which were decontaminated with aqueous chlorhexidine based preparations more suitable for skin disinfection. 'In the medium risk group most doubtful methods were chemical disinfection used when heat disinfection would be more appropriate, and most unsatisfactory methods were due to either washing such items or not decontaminating them at all. In the low risk category only items not treated in any way were judged as doubtfully decontaminated.

All the autoclaves and hot water disinfectors were in good working order, as indicated by brief technical checks. All the autoclaves were controlled automatically and worked on preset cycles, so that all the operator needed to do was press one button to initiate a cycle. In all five practices with autoclaves these were either still under guarantee or covered by some form of service contract, though, as this was sometimes with a

\section{BOOKS RECEIVED}

\section{Acquired immune deficiency syndrome \\ Bichazard: the Silent Threat from Biomedical Research and the Creation of AIDS. A Report by the National Anti- Vivisection Society. Ld J Creamer. (Pp 120; figs; £3 paperback.) London National Anti-Vivisection Society,} 1987. ISBN 0-905225-07-4.

Addiction

World Health Organisution Technical Report Series. No 761. "WHO Expert Committee on Drug Dependence." Twenty-fourth Report. Fenty-fourth Report. (Pp 36; Sw rs 6 paperback. Geneva: World Health $20761-2$

\section{Alternative medicine}

Aromatherapy for Everyone. $\mathrm{R}$ Tisserand. ( $P$ p 240; 53.95 paperback.) London: Penguin, 1988. ISBN 0-14 009683-3.

Bodymind Energetics. Toward a Dynamic Model of Healih. M Seem Pp 272; figs; 66.99 paperback. Wellingborough: Thorsons, 1988 ISBN 0-7225-1603-7.

Herbal Medicine for Everyone. $\mathrm{H}$ McIntyre. (Pp 176; figs; $£ 3.95$ paperback.) London; Penguin, 1988. ISBN back.) London;

Hypnotherapy for Everyone. $\mathrm{R}$ Lever (Pp 176; £3.95 paperback.) London: Penguin, 1988. ISBN 0-14-010138-1.
Osteoputhy for Ezervone. P Masters. Pp 212; $\{4.95$ paperback.) London: Penguin, 1988. ISBN 0-14-009321-4. Spiritual and Lav Healing. P Pullar. Pp 192; £3.95 paperback.) London: Penguin, 1988. ISBN 0-14-009639-6.

Anatomy

The Protolohar Structure of the Human Kidnev. Its Biologic and Clinical Significance. G Inke. (Pp 808; figs; \$275.) New York: Liss, 1988. Distributed by John Wiley and Sons. ISBN 0-84514234-8.

\section{Biology}

Macromolecular Sequencing and Synthesis. Selected Methods and Applicahons. Ed D H Schlesinger. (PP 284 figs; $\$ 69.50$.$) New York. Liss, 1988$ Distributed by John Wiley and Sons. ISBN 0-8451-4246-1.

Modem Bioelectricity. Ed A A Marino. (Pp 1072; figs; \$179.50.) New York: Dekker, 1988. ISBN 0-8247-7788-3. Receptor Biochemistry and Methodolo Vol 11. "Adenosine Receptors." Ed
D M F Cooper, C Londos. Series D M F Cooper, C Londos. Series
editors J C Venter, L C Harrison. (Pp editors J C Venter, L C Harrison. (Pp
$152 ;$ figs; $\$ 42$.) New York: Liss, 1988. Distributed by John Wiley and Sons. ISBN 0-8451-3710-7

Cardiology

Betu-blockers in Clinical Practice.
J M Cruickshank, B N C Prichard. Pp 1020: figs; C95) Ediahurg: Churchill Livings 1987 . ISBN Churchill Li

Doppler Color Flow Imaging. J Kisslo, D B Adams, R N Belkin. (Pp 200 colour plates; 245 .) New York: Churchill Livingstone, 1988. ISBN 0-443. 08563-3.

Recent Advances in Cardiologv. No 10 Ed D J Rowlands. (Pp 280; figs; 138 . Edinburgh: Churchill Livingstone, 1987. ISBN 0-443-03527-X

Cardiovascular system

Studies in Neuroscience. "The Neurobiology of the Cardiorespiratory System." Ed E W Taylor. Series edito W Winlow. (Pp 440; figs; $£ 47.50$.) Manchester: Manchester University Press, 1988. ISBN 0-7190-2452-8.

\section{Communication disorders}

Decision in Speech-Language Pathologv. D E Yoder, R D Kent. (Pp 232; figs; D E Yoder, R D Kent. (Pp 232; figs;
227.50.) Toronto: Decker, 1988. Distributed by Blackwell Scientific. ISBN
ther 0-941158-91-8.

\section{Community medicine}

Daughters Who Care: Daughters Carin for Mothers at Home. J Lewis, B Meredith. (Pp 208; 18.95 paperback. London: Routledge, 1988. ISBN 0-415-00682-1.

\section{Dermatology}

The Sun and Your Skin. R Marks. (P 128; figs; £5.99 paperback.) London Macdonald Optima, 1988. ISBN $0-356-14740-1$

\section{Endocrinology}

Fundamentals of Endocrinology. W R Slaunwhite, Jr. (Pp 440; figs; \$54.) New York: Dekker, 1988. ISBN \$54.) New York:
$0-8247-7714-X$

Immunogenetics of Endocrine Disorder Ed N R Farid. (Pp 528; figs; $\$ 110$. New York: Liss, 1988. Distributed by John Wiley and Sons. ISBN 0-84514245-3.

Environmental and public health

IPCS International Programme on Chemical Safety: Environmental Health Criteria 68. "Hydrazine." United Nations Environment Programme International Labour Organisatio World Health Organisation. (Pp 92; Sw frs 10 paperback.) Geneva: World Health Organisation, 1987. ISBN 92 4-154268-3.

IPCS International Programme on Chemical Safetv: Environmental Health Criteria 69. "Magnetic Fields." United Nations Environment Programme/World Health Organisation/ International Radiation Protection Association. (Pp 200; figs; Sw frs 16 paperback.) Geneva: World Health
Organisation, 1987. ISBN 924. 154269-1.

IPCS International Programme on Chemical Safely: Environmental Health Criteria 74. "Diaminotoluenes." United Nations Environment Programme International Labour Organisation World Health Organisation. Ww frs 9 paperth Organisation. (Pp 68 Sw frs 9 paperback.) Geneva: World Health Orga

IPCS International Programme on Chemical Safety: Environmental Health Criteria 75. "Toluene Diisocyanates." United Nations Environment Programme/International Labour Organisation/World Health Organisation. Pp 72. Sw frs 9 paperback) (Pp 72; Sw frs 9 parerback.) Geneva: ISBN 92-4-154275-6.

General practice

Dizziness: a Guide to Disorders of Balance. T Wright. (Pp 270; figs and colour plates; $£ 15.95$ paperback. London: Croom Helm, 1988. ISBN 0-7099-3659-1.

Genetics

Klinefelter's syndrome in Childhood, Adolescence and Youth: a Genetic, Clinical, Developmental, Psychiatric and Psychological Study. K Sørensen. (Pp 312; figs; £45.) Carnforth: Parthenon, 1988. ISBN 0-940813-28-9. 
local retail electrician, detailed knowledge of autoclave test procedures and maintenance could not always be ensured. Service intervals were reported to range from two to six months.

One of the hot water disinfectors had integral thermostatic control which kept its contents at between $71^{\circ} \mathrm{C}$ and $85^{\circ} \mathrm{C}$. All the others gave rise to actively boiling water. None had door locks linked to thermostatically tripped timers such that instruments could not be removed before a preset time immersed at a preset temperature, though evidently hot water disinfectors with these desirable features are not available.

The hot air oven was confusing to operate in that the temperature control dial was too small to set accurately, and when set to $180^{\circ} \mathrm{C}$ it cycled at between $165^{\circ} \mathrm{C}$ and $185^{\circ} \mathrm{C}$. Further difficulties were encountered in setting the sterilisation time, as the timer started from the initiation of the cycle rather than from attainment of the set sterilisation temperature.

Though no disinfectant sampled showed evidence of bacterial contamination, the choice of disinfectant was often inappropriate for the chosen task, both in microbicidal range and in working dilution.

Only six of the 20 practices used hypochlorites (the most appropriate decontaminating agent) for spills of blood and body fluids. ${ }^{2}$ The rest used a wide variety of decontamination methods, possibly centred on whatever agent was available closest to the spill. Agents more appropriate to skin disinfection such as aqueous chlorhexidine or chlorhexidine and cetrimide mixtures' were frequently used for the combined cleaning and disinfection of medium risk items.

\section{Discussion}

This small survey was designed to highlight the main problems common to general practice and cannot be extrapolated to provide national statistics of methods of decontamination. The means by which practices were chosen-that is, by established links with those organising the study - was likely to provide a more enthusiastic survey population. Enlarging the numbers in the survey would merely have provided greater detail on a biased population rather than generating more reliable information on general practice as a whole. The overall effect of this was to reduce the apparent magnitude of any problems rather than misrepresent them.

After each practice had been surveyed participants could, if they wished, get an informal assessment of their decontamination methods and receive advice on any improvements needed. There was an encouraging willingness to gain feedback from the survey, and many participants expressed concern at the difficulties that they had encountered in previous attempts to find such information.

The autoclave was the most efficient and reliable means of decontamination used by the practices surveyed. All of those surveyed were operated by a push button on a preset cycle. All that the operator (usually the practice nurse) had to do was load the autoclave, charge it with distilled or deionised water, and start the cycle. In contrast, the one hot air oven found in the survey needed thermometric monitoring to set the variables for a sterilising cycle, and the hot water disinfectors (12 out of 13 of which boiled) had neither lid locks nor integral timing mechanisms and needed operator vigilance to ensure that items were adequately disinfected. Boiling water will not kill bacterial spores and so cannot be used for decontaminating items that are required to have been sterilised, though, interestingly, many of those taking part in the survey still used the traditional misnomer "steriliser" when referring to a hot water disinfector.
Monitoring the efficacy of a steriliser is best done by regular servicing of the apparatus rather than by using indicator strips or tapes. These chemical indicators may distinguish loads that have and have not been through a steriliser but cannot be relied on to assess accurately whether sterilisation parameters have been met. Biological indicators (spore strips or tubes) may be misleading and require exacting culture conditions over lengthy incubation times and therefore should not be used. Servicing should be carried out by the manufacturer or any other competent steriliser engineer every six months if use is light (twice daily or less) or every four months otherwise. Monitoring internal temperature by independent thermocouples should be included in the service at least yearly.

Though we realise that our classification of risk may contain apparent anomalies, such as putting neurological examination pins in a higher category than vaginal speculums, this is already accepted for syringe needles, and technical difficulties in decontaminating these pins successsfully make it desirable that they should be single use and presterilised. Such pins are commercially available.

The overall use of chemical disinfectants took little account of their microbicidal range or of the time that they needed to work. This was shown in the use of skin disinfectants with limited microbicidal range for instrument decontamination and in the frequent use of alcohol, a wide spectrum microbicide, as a wipe which gives a very brief contact time between disinfectant and target. Chemical disinfectants are not acceptable for high risk items for which sterility is required and should be acceptable only for thermolabile, medium risk items incapable of being sterilised or disinfected by heat and which cannot be provided as single use items.

Of the disinfectants readily available to general practitioners, the most useful are hypochlorites and alcohols. Hypochlorites, as either liquid bleaches or powders, are for use on spills of body fluids, ${ }^{2}$ especially if there is a risk of hepatitis B virus or human immunodeficiency virus. Alcohol, as either ethanol (usually as industrial methylated spirit) or isopropanol, should be used at a $70 \%$ concentration as a soaking solution for 10 minutes for thermolabile instruments such as thermometers. Alcohol wipes tend to provide incomplete cover and short exposure and should not be used.

Even when a practice has a steriliser it may still be necessary to buy commercially available presterile items such as intrauterine devices, which need specialised conditions for sterilisation that cannot be attained in a simple autoclave. As it is possible to buy the items that need to be sterile in a presterile, single use form, practices can be organised in such a way that they do not need a steriliser, though they will need a hot water disinfector to decontaminate medium risk items. This must be judged individually by each practice. It may also be possible for practices to arrange for sterilisation with their local hospital central sterile supply department, though this was rare among participants in this study.

We are grateful to all the general practitioners and practice nurses who took part in this study. We also thank Lynda Taylor, Jane Hopkin, and Dr N F Lightfoot for valuable help.

1 Aycliffe GAJ, Coates D, Hoffman PN. Chemical disinfection in hospitals. London: Public Health Laboratory Service, 1985.

2 Department of Health and Social Security. Acquired immune deficiency syndrome. Booklet 3. Guidance for surgeons, anaesthetists, dentists and their teams in dealing with patients infected with HTLV III. London: Department of Health and Social Security, 1986.

(Accepted 6 April 1988) 